\title{
Artikel
}

\section{Witwassen en deelname aan een criminele organisatie als vangnet voor indirecte betrokkenheid van ondernemingen bij mensenrechtenschendingen}

\author{
Een analyse van de aangifte tegen de Rabobank
}

Mr. dr. M.J. Hornman*

\section{Inleiding}

In februari 2017 is door de heer Hernandez en de nongouvernementele organisatie SMX Collective aangifte gedaan tegen de Coöperatieve Rabobank U.A., de Rabobank International Holding B.V. en de Utrecht-America Holding Inc., tezamen aangeduid als de Rabobank Groep, en tegen diverse leidinggevenden van deze groep. De beschuldigingen an het adres van - kortweg - de Rabobank komen erop neer dat de bank grote sommen geld zou hebben witgewassen voor diverse Mexicaanse drugskartels (art. 420bis e.v. Sr). Het zou daarbij gaan om aanzienlijke uit drugshandel in de Verenigde Staten afkomstige contante bedragen die door een lokale vestiging in Calexico nabij de Amerikaans-Mexicaanse grens zouden zijn geaccepteerd en die vervolgens op geraffineerde wijze zouden zijn doorgesluisd naar meerdere rekeningen waardoor hun oorspronkelijke criminele herkomst niet meer kan worden achterhaald. Door aldus te opereren zou de Rabobank deze drugswinsten niet alleen hebben witgewassen, maar ook hebben bijgedragen an de herinvestering van deze bedra-

* Mr. dr. M.J. Hornman is universitair docent straf- en strafprocesrecht aan de Vrije Universiteit Amsterdam. gen in de criminele bedrijfsvoering van de kartels en daarmee aan het bestendigen en verder uitbouwen van de reeds bestaande machtspositie van deze kartels en hun criminele activiteiten. ${ }^{1}$ Als financiële dienstverlener vormde de Rabobank een onmisbare schakel in dat proces. Medewerking van legitieme economische actoren is immers cruciaal voor het succes van georganiseerde criminele netwerken. ${ }^{2}$ Volgens de aangifte heeft de Rabobank door de kartels op deze manier behulpzaam te zijn in belangrijke mate bijgedragen aan het leed dat door deze kartels wordt veroorzaakt. Zelfs op een dusdanige wijze dat de bijdrage van de Rabobank zou moeten worden aangemerkt als het deelnemen aan de criminele organisaties die door deze kartels worden gevormd (art. $140 \mathrm{Sr}) .^{3}$

In deze bijdrage worden maatschappelijke en juridische achtergronden van deze beschuldigingen nader geanalyseerd en wordt beoordeeld in hoeverre de strafbaarstellingen inzake witwassen en deelname aan een criminele

1. Zie 'Aangifte tegen de Rabobank Groep', daterende van 2 februari 2017 (vindplaats: http://www.prakkendoliveira.nl/nl/nieuws/aangiftetegen-rabobank-groep-vanwege-witwassen-van-winsten-vanmexicaanse-drugskartels/).

2. E.W. Kruisbergen e.a., Georganiseerde criminaliteit in Nederland. Vierde rapportage op basis van de Monitor Georganiseerd Criminaliteit, Den Haag: Boom Lemma uitgevers 2012; B. Unger, The Scale and Impacts of Money Laundering, Cheltenham: Edward Elgar Publishing 2007.

3. Aangifte, p. 18-19. 
organisatie een effectief en passend antwoord kunnen vormen op indirecte betrokkenheid van ondernemingen bij grove mensenrechtenschendingen. De Rabobankcasus zal daarbij als voorbeeld dienen om de concrete uitwerking van beide opties nader te illustreren. Daartoe zal in paragraaf 2 allereerst nader worden ingegaan op de omvang en achtergrond van de Mexicaanse drugsproblematiek en de problemen die rijzen bij het aanspreken van ondernemingen op zijdelingse betrokkenheid bij dergelijke ernstige strafbare feiten. Veelal is die betrokkenheid te beperkt en te indirect om deze nog langs de weg van de reguliere deelnemingsvormen te kunnen vervolgen. In de literatuur zijn daarom alternatieven voorgesteld die mogelijk effectiever kunnen zijn bij het redresseren van die indirecte betrokkenheid: witwassen en deelname aan een criminele organisatie. Niet geheel toevallig zijn dit exact de verwijten die de Rabobank worden gemaakt. De beschuldigingen inzake witwassen zullen in paragraaf 3 nader worden geanalyseerd. In paragraaf 4 volgt eenzelfde beschouwing van het vermeende deelnemen aan een criminele organisatie. De bijdrage sluit af met een slotbeschouwing in paragraaf 5 . $\mathrm{Nu}$ de aangifte zich concentreert op de aansprakelijkheid naar Nederlands recht voor de Nederlandse rechter, blijft de vraag naar aansprakelijkheid van de bank onder Amerikaans recht buiten beschouwing. De nadruk zal bij de bespreking liggen op de materieel strafrechtelijke vereisten voor aansprakelijkheid in concernverhoudingen. Op de vraag in hoeverre de Nederlandse rechter ook rechtsmacht zou hebben wordt niet ingegaan.

\section{Omvang en achtergrond van de problematiek}

De vergaande macht, het extreem gewelddadige karakter en de mate waarin deze kartels zijn geinfiltreerd in en hun stempel weten te drukken op nagenoeg alle sectoren van de Mexicaanse samenleving, zijn nauwelijks te bevatten. Geen middel wordt geschuwd om doelen te bereiken - moord, verkrachting en marteling zijn aan het orde van de dag; het moordcijfer in Mexico voor 2017 nadert de 25 duizend $^{4}$ - en daarbij doet niet ter zake of de slachtoffers nu tegenstanders of onschuldige passanten zijn. De overheid is niet in staat, en deels ook niet bereid, om deze machtspositie te doorbreken. De infiltratie gaat immers zo ver dat het politieke bestuur vergaand is gecorrumpeerd en deel uitmaakt, dan wel (noodgedwongen) aan de leiband loopt van de drugskartels, hetzij uit lijfsbehoud, hetzij omdat het ambtelijke apparaat vergaand is geïnfesteerd met kartelleden, sympathisanten of mensen die het simpelweg niet aandurven om tegen de kartels in te gaan. De politie vormt hierop helaas geen uitzondering, zoals de tragedie uit 2014 waarbij een lokale eenheid ruim veertig studenten

4. S. Kester, 'Mexico zucht onder drugsmoorden', de Volkskrant 12 december 2017 ontvoerde en overdroeg aan een kartel, hetgeen naar alle waarschijnlijkheid in hun dood heeft geresulteerd, heeft laten zien. ${ }^{5}$ Zicht op enige verbetering lijkt te ontbreken. De mensenrechtensituatie lijkt alleen maar te verslechteren en uit te monden in totale uitzichtloosheid. Het is tegen deze achtergrond dat de noodkreet die achter de aangifte schuilgaat, moet worden gezien.

De aangifte maakt onderdeel uit van een bredere wereldwijde campagne onder de slogan 'Money laundering is not a victimless crime', ${ }^{6}$ waarmee direct de kern van de problematiek wordt belicht. Bij eerste aanblik ziet de strafbaarstelling van witwassen namelijk op relatief op zichzelf staande gedragingen die duidelijk zijn verwijderd van het grondfeit waaruit de voorwerpen zijn verkregen of het vervolgfeit dat daarmee, na een succesvol witwastraject, kan worden begaan. Die afstand typeert ook de betrokkenheid van veel westerse ondernemingen bij grove mensenrechtenschendingen. Doorgaans is deze betrokkenheid indirect van aard. De onderneming begaat die schendingen niet zelf, maar raakt betrokken bij schendingen die door anderen worden begaan. De onderneming vervult daarbij eigenlijk de rol van facilitator, bijvoorbeeld door technische middelen, knowhow of logistieke ondersteuning te leveren waarmee deze misdrijven kunnen worden begaan, maar ook door zelf (indirect) van dergelijke misdrijven te profiteren door goederen of diensten af te nemen van de partijen die deze mensenrechtenschendingen plegen. ${ }^{7}$ Veelal staat de onderneming in meerdere opzichten op te grote afstand van die strafbare feiten om nog als deelnemer te kunnen worden aangemerkt. Burchard spreekt in dit kader van 'multiple layers of accumulated (factual and normative) remoteness' die het vaststellen van aansprakelijkheid vergaand compliceren, mede doordat deze factoren elkaar onderling versterken. ${ }^{8}$ Deze afstand is er in causaal opzicht (causal remoteness) nu de gedragingen van de onderneming niet direct zijn gericht op het begaan van mensenrechtenschendingen maar eerder een op zichzelf staand en overwegend neutraal karakter zullen hebben. Het is de wijze waarop de bijdrage van de onderneming later door anderen wordt aangewend en een plaats krijgt binnen hun strafbare gedraging, waardoor deze bijdrage opeens een schadelijk karakter krijgt, terwijl die handelingen op zichzelf beschouwd niet inherent schadelijk zijn. Het verlenen van financiële diensten is hiervan een helder voorbeeld. Voorts handelt een onderneming vanuit economische motieven. Haar intenties zullen daardoor in de regel afwijken van het opzet

5. M. van de Water, 'Hoe de 43 Mexicaanse studenten op lugubere wijze verdwenen', de Volkskrant 9 november 2014 (www.volkskrant.nl); https://nos.nl/op3/artikel/2003132-tijdlijn-de-mexicaansestudentenmoorden.html

6. https://moneylaunderingkills.nl/.

7. W. Huisman, Business As Usual? De betrokkenheid van ondernemingen bij internationale misdrijven (oratie VU), Den Haag: Eleven International Publishing 2010, p. 11; C. Burchard, 'Regulating Business with Bad Actors: Aiding and Abetting and Beyond', Texas International Law Journal: The Forum, Vol. 50 (3), 2015, p. 1.

8. C. Burchard, 'Ancillary and Neutral Business Contributions to 'Corporate-Political Core Crime': Initial Enquiries Concerning the Rome Statute', Journal of International Criminal Justice, Vol. 8 (3), 2010, p. 925. 
van de primaire mensenrechten schendende daders, zodat er ook in dat opzicht een zekere distantie bestaat tot het door hen begane grondfeit (motivational remoteness). Tot slot staat de onderneming ook in fysiek (geografisch), organisatorisch en structureel opzicht op aanzienlijke afstand van die strafbare feiten (organizational and structural remoteness). 'De' Rabobank Groep zoals deze in de beschuldigingen wordt geduid, is in werkelijkheid geen eenheid maar een multinationaal netwerk van meerdere onderling verbonden, maar nog steeds zelfstandige rechtspersonen, gevestigd op meerdere locaties. Het gaat hier om rechtspersonen die in vergaande mate zelfstandig opereren en zelfstandig zijn georganiseerd, en zodoende dus gescheiden organisaties vormen.

In casu gaat het om gedragingen die zijn verricht op een kleine, relatief onbeduidende vestiging van de Rabobank nabij de Amerikaans-Mexicaanse grens. Deze vestiging maakt onderdeel uit van Rabobank North America; een zelfstandige rechtspersoon die geen deel uitmaakt van de voornoemde groep. Dat roept de vraag op in hoeverre de gedragingen en de kennis van dat lokale filiaal en zijn medewerkers ook aan andere onderdelen van de Rabobank kunnen worden toegerekend. Het gaat hier immers om autonome rechtssubjecten. Daar komt bij dat elke rechtspersoon een eigen bedrijfsvoering en eigen taken en verantwoordelijkheden heeft, hetgeen doorwerkt in de onderlinge informatie-uitwisseling en de daadwerkelijk feitelijke verhoudingen binnen het Rabobankconcern. Daarbij laat de Rabobank zich nog steeds voorstaan op haar coöperatieve karakter, ${ }^{9}$ waarbij het beleid van de bank voor een aanzienlijk deel op decentraal niveau wordt bepaald. Aldus gaat het hier om organisaties die zowel de jure als de facto in meerdere opzichten van elkaar zijn gescheiden. Al deze factoren maken het lastig om de in de Verenigde Staten begane misstanden terug te voeren naar het hoofdkantoor en de raad van bestuur in Nederland zoals de aangifte bepleit.

\section{De bank als witwasser}

Als directe betrokkenheid in de zin van reguliere deelneming niet kan worden vastgesteld, rijst de vraag of er geen alternatieve wegen zijn waarlangs deze meer indirecte betrokkenheid alsnog kan worden aangepakt. In de literatuur zijn twee van die opties prominent naar voren gekomen: witwassen en deelname aan een criminele organisatie. ${ }^{10}$ Beide strafbaarstellingen hebben als voor-

Dat het aantal coöperaties sinds haar oprichting als gevolg van samenvoegingen flink is geslonken en dat de wijze waarop die coöperaties tegenwoordig worden bestuurd aanzienlijk is gewijzigd, doet daaraan niet af.

10. F.G.H. Kristen, 'Maatschappelijk verantwoord ondernemen en strafrecht', in: Maatschappelijk verantwoord ondernemen (Handelingen Nederlandse Juristen-Vereniging 2010-1), Deventer: Kluwer 2010, p. 146-155. L. Enneking e.a., Zorgplichten van Nederlandse ondernemingen inzake internationaal maatschappelijk verantwoord ondernemen. Een rechtsvergelijkend en empirisch onderzoek naar de stand van het deel dat zij zich goed lenen voor het aanspreken van partijen die een meer faciliterende rol vervullen bij door anderen begane strafbare feiten. Bij witwassen komt dat ook prominent tot uiting in de ratio van de strafbaarstelling: de bescherming van de aantasting van de integriteit van het financieel en economisch verkeer en het voorkomen van bedreigingen voor de openbare orde. ${ }^{11}$ Het is door de gecreëerde schijn van legaliteit dat verkregen illegale drugsgelden grootschalig kunnen worden ge(her)investeerd in de legitieme economie. Hierdoor blijft de drijfveer om dergelijke delicten te begaan bestaan en treedt een ondermijnend effect op nu het vertrouwen van de samenleving in maatschappelijke structuren, instanties en verhoudingen wordt geschaad. ${ }^{12}$ Dat die maatschappij-ontwrichtende gevolgen verstrekkend kunnen zijn, laat de invloed van de drugskartels op de Mexicaanse samenleving overduidelijk zien.

Dat roept de vraag op of een vervolging van de Rabobank Groep wegens witwassen enige kans van slagen zou kunnen hebben en of een vervolging ter zake van dit specifieke delict zou kunnen bijdragen aan het oplossen van het probleem van afstandelijke betrokkenheid.

\subsection{De argumentatie uit de aangifte}

In de aangifte wordt de claim dat de Rabobank zich schuldig zou hebben gemaakt aan witwassen als volgt onderbouwd. ${ }^{13}$ Allereerst worden het bovenstaande geschetste gewelddadige karakter van de kartels, de verwevenheid tussen onder- en bovenwereld en het gegeven dat de kartels afhankelijk zijn van de medewerking van de bancaire sector, als feiten van algemene bekendheid geponeerd, zodat ook de Rabobank geacht moet worden daarvan op de hoogte te zijn geweest. Voorts wordt gesteld dat de bank door de Amerikaanse autoriteiten eerder en herhaaldelijk is gewezen op de omstandigheid dat haar interne toezicht inzake witwaspreventie tekort zou schieten, waarbij de vestiging in Calexico ook expliciet ter sprake zou zijn gekomen. Het in de VS lopende strafrechtelijk onderzoek naar grootschalig witwassen, waarvoor aanvankelijk $€ 310$ miljoen was gereserveerd,${ }^{14}$ is recentelijk geëindigd in een schikking van $€ 298$ miljoen. ${ }^{15}$ Het voor witwassen benodigde opzet

Nederlandse recht in het licht van de UN Guiding Principles, Den Haag: Boom juridisch 2016, p. 227. Andere opties, zoals het overtreden van de Sanctiewet en de Wet ter voorkoming van witwassen en financieren van terrorisme, blijven hier buiten beschouwing.

11. HR 26 oktober 2010, NJ 2010, 655 m.nt. Keijzer; F. Diepenmaat, De Nederlandse strafbaarstelling van witwassen. Een onderzoek naar de reikwijdte en de toepassing van artikel 420bis Sr (diss. Nijmegen), Deventer: Kluwer 2016, p. 64; Kristen 2010, p. 147 (met verdere verwijzingen naar richtlijnen en kamerstukken).

12. Kruisbergen e.a. 2012 , p. 264

13. Aangifte, p. 11-17 (met een puntsgewijze opsomming op de laatste pagina).

14. R. Betlem, 'Rabobank zet $€ 310 \mathrm{mln}$ opzij wegens dreigende Amerikaanse boete', Het Financieele Dagblad 3 januari 2018 (www.fd.nl).

15. M. van de Water, 'Rabo schikt witwaszaak in VS voor 298 miljoen euro', de Volkskrant 8 februari 2018. Zie voor de press release van het U.S. Attorney's Office van het Southern District of California van het Amerikaanse Department of Justice: https://www.justice.gov/ usao-sdca/pr/bank-pleads-guilty-pays-historic-penalty-concealing-antimoney-laundering-failures. 
zou volgens de aangifte zijn af te leiden uit de reactie van de Rabobank. In weerwil van de signalen dat er een substantieel witwasrisico was, dat zich naar het zich laat aanzien ook op grote schaal heeft verwezenlijkt, zou de bank het aantal toezichthoudende medewerkers fors hebben teruggebracht. Bovendien werd het toezicht uitgeoefend vanaf een andere vestiging. Mede daardoor zouden verdachte stortingen en ongebruikelijke transacties op aanzienlijke schaal niet zijn opgemerkt en/of gemeld. Concluderend stelt de aangifte dat de bank heeft verzuimd adequaat toezicht te houden en doelbewust op grote schaal heeft toegelaten dat witwasactiviteiten zouden worden ontplooid, althans dat de bank de aanmerkelijke kans daarop bewust heeft anvaard. ${ }^{16}$ $\mathrm{Nu}$ de witwasactiviteiten langdurig en stelselmatig hebben plaatsgevonden, zou bovendien sprake zijn van gewoontewitwassen (art. 420ter lid $1 \mathrm{Sr}$ ), terwijl de verweten feiten ook nog eens zijn verricht als onderdeel van de bedrijfsvoering (art. 420ter lid $2 \mathrm{Sr}$ ).

\subsection{De witwasgedraging}

Het gegeven dat veel in de aangifte naar voren gebrachte feiten niet kunnen worden geverifieerd en ook niet onomstotelijk zijn vastgesteld, dwingt tot een zekere terughoudendheid. Niettemin roept de casus diverse juridisch interessante vragen op, in het bijzonder aangaande het relatief onontgonnen terrein van toerekening van gedragingen en opzet in concernverhoudingen en de rol die het delict witwassen kan spelen bij het aanpakken van zijdelingse betrokkenheid bij strafbare feiten. Dat de feiten nog niet geheel vaststaan, biedt daarbij zelfs mogelijkheden om de vraag naar toerekening binnen concernverhoudingen nader te problematiseren aan de hand van verschillende mogelijke scenario's. Dat zal in het navolgende dan ook geschieden.

In essentie liggen in casu drie vragen voor: 1) is er sprake van een witwasgedraging? 2) is er sprake van wetenschap (opzet)? en 3) kunnen die gedraging en kennis worden toegerekend aan een of meerdere rechtspersonen binnen het Raboconcern? ${ }^{17}$ Voor wat betreft het eerste is het opvallend dat de aangifte zich enkel toespitst op het verborgen houden of verhullen van de criminele herkomst van het door de bank ontvangen geld als bedoeld in artikel 420bis lid 1 sub a Sr. Gedragingen uit sub $b$ worden niet aangehaald. Wanneer van dergelijk verborgen houden of verhullen exact sprake is, is niet geheel duidelijk. Beide begrippen zijn ruim

16. Aangifte, p. 13-14.

17. De term 'toerekening' wordt daarbij ruim opgevat en omvat naast toerekening in klassieke zin - het toerekenen van een gedraging van $A$ aan $B$ - ook het aanmerken van de feitelijke handelingen van een ander ( van A) als een uitvloeisel van de eigen gedraging (van B). (Zie over de verschillende interpretaties van het concept toerekening nader: E. Gritter, 'Duidelijkheid omtrent corporatief daderschap. Enige beschouwingen naar aanleiding van het Drijfmest-arrest', Tijdschrift voor Onderneming en Strafrecht 2004 (2), p. 33-34; M.J. Hornman, De strafrechtelijke aansprakelijkheid van leidinggevenden van ondernemingen. Een beschouwing vanuit multidimensionaal perspectief (diss. Utrecht), Den Haag: Boom juridisch 2016a, p. 45-46; S.N. de Valk, Aansprakelijkheid van leidinggevenden (diss. Groningen), Deventer: Kluwer 2009, p. 310-311.) omschreven verzameltermen. ${ }^{18}$ Bovendien gaat het bij vervolgingen ter zake van witwassen altijd om witwastrajecten die zijn mislukt. Bij een geslaagd verhullen valt de criminele herkomst immers niet meer te achterhalen. ${ }^{19}$ Deze gedragingen zullen derhalve vooral moeten worden beoordeeld op hun gerichtheid: strekken zij ertoe om het zicht op de herkomst te bemoeilijken? Daarbij staat niet de intentie van de verdachte, maar de objectieve strekking van de gedraging zelf centraal. Bepalend is of de handelingen gericht en geschikt zijn om het zicht op de herkomst van de voorwerpen te bemoeilijken. ${ }^{20}$ Of daarvan sprake is, zal grotendeels afhangen van de wijze waarop het vermogen bij de bank is aangebracht, de titel waaronder het geld op de rekeningen wordt gestort en aan wie deze rekeningen toebehoren. De aangifte geeft daarover helaas weinig duidelijkheid. Indien die stortingen bijvoorbeeld de suggestie zouden wekken dat er sprake is van een legitieme transactie in de zakelijke of familiaire sfeer, dan kan worden gesteld dat er sprake is van een versluierend element dat bedoeld is om het zicht op de werkelijke criminele herkomst te ontnemen. ${ }^{21}$ Uit de jurisprudentie over het opgaan van de kwalificatie-uitsluitingsgrond bij het verwerven of voorhanden hebben van vermogen dat onmiddellijk uit eigen misdrijf afkomstig is (art. 402bis lid 1 sub b Sr), ${ }^{22}$ welke nadien ook van toepassing is verklaard op bepaalde gevallen van omzetten en overdragen, ${ }^{23}$ kan worden afgeleid dat het enkel storten van dat bedrag op de eigen bankrekening, en daarmee het transponeren van chartaal in giraal geld, nog niet zonder meer verhullen oplevert en dat een bijkomende op het daadwerkelijk verbergen of verhullen van de criminele herkomst van die geldbedragen gerichte gedraging noodzakelijk is. ${ }^{24} \mathrm{Nu}$ het laten storten en bijschrijven van de geldbedragen op betaalrekeningen het kernverwijt is aan het adres van de bank, is dat gegeven niet zonder betekenis. ${ }^{25}$ Keulen merkt op dat de Hoge Raad terughoudend is bij het aannemen dat een gedraging de criminele herkomst van een voorwerp verhult. ${ }^{26} \mathrm{De}$ bank zal dus meer moeten hebben gedaan om aansprake-

18. Diepenmaat 2016, p. 66.

19. Kamerstukken II 1999/2000, 27 159, nr. 3, p. 14-15; Borgers in diens noot onder HR 8 januari 2013, NJ 2013/266, punt 9.

20. Kamerstukken I/ 1999/2000, 27 159, nr. 5, p. 17; HR 14 februari 2017, NJ 2017/377 m.nt. Keulen; Diepenmaat 2016, p. 66-67.

21. Vgl. Borgers in diens noot onder HR 8 januari 2013, NJ 2013/266, punt 8 over het stoppen van crimineel geld in een enveloppe en deze voorzien van het opschrift 'opbrengst vrijmarkt Koningsdag'.

22. HR 26 oktober 2010, NJ 2010/655 m.nt. Keijzer; HR 8 januari 2013, NJ 2013/266 m.nt. Borgers.

23. HR 25 maart 2014, ECLI:NL:HR:2014:716; HR 13 december 2016, NJ 2017/218 m.nt. Mevis.

24. HR 7 oktober 2014, NJ 2014/500 m.nt. Keijzer; HR 27 oktober 2015, NJ 2016/83 m.nt. Keulen; HR 8 november 2016, NJ 2016/479. Blijft een dergelijke verhullende gedraging achterwege, dan vindt de kwalificatie-uitsluitingsgrond toepassing.

25. Opgemerkt zij overigens dat het verbergen of verhullen van de herkomst van het geld iets anders is en ook meer vergt dan het verbergen of verhullen van het geld zelf (zie o.a. HR 8 januari 2013, NJ 2013/264; HR 8 januari 2013, NJ 2013/266 m.nt. Borgers; HR 19 februari 2014, ECLI:NL:HR:2014:3687; HR 20 mei 2014, ECLI:NL:HR:2014:1164; HR 14 oktober 2014, NJ 2014/478).

26. Keulen in diens noot onder HR 14 februari 2017, NJ 2017/377, punt 4. 
lijk te zijn dan het enkel hebben laten bijschrijven van crimineel geld op een bankrekening. Door de Hoge Raad erkende verhullende gedragingen zijn: het na storting wederom contant opnemen van het bedrag, ${ }^{27}$ het aanwenden van dat geld voor betalingen van onroerend goed $^{28}$ en het laten of doen storten van de desbetreffende bedragen op de derdenrekening van een notaris. ${ }^{29}$ Geen van deze voorbeelden biedt direct uitsluitsel voor de hier voorliggende casus. Voor zover in casu sprake is geweest van voornoemde of gelijksoortige gedragingen, hebben deze later in het witwastraject plaatsgevonden en zijn deze gedragingen niet door bankmedewerkers verricht. Aansprakelijkheid van de bank zal dus langs een andere route moeten worden geconstrueerd.

Een conclusie van A-G Vegter uit 2014 biedt daarvoor interessante aanknopingspunten. In de desbetreffende casus zag de A-G zich gesteld voor de vraag of het niet (volledig) melden van de staat van inkomen en vermogen bij de curator in geval van een faillissement (de verdachte werd verweten zijn uit eigen misdrijf verkregen inkomsten te hebben verzwegen), kon worden aangemerkt als verhullen of verbergen. De A-G beantwoordt die vraag positief. ${ }^{30}$ Het ging in casu immers om een bijzondere, enkel op de gefailleerde rustende rechtsplicht. De vergelijking met $N \mathcal{F}$ 2013/264 waarin vermogen buiten het zicht van de belastingdienst werd gehouden, en waarvan de Hoge Raad oordeelde dat dit geen verhulling opleverde, zou om die reden niet opgaan aangezien het doen van een correcte belastingaangifte een algemene rechtsplicht is die op eenieder rust. De Hoge Raad kwam aan het door de A-G opgeworpen punt niet toe omdat hij, anders dan de A-G, niet van mening was dat afdoende was gebleken dat het aangetroffen geldbedrag uit misdrijf afkomstig was. ${ }^{31} \mathrm{Op}$ de Rabobank rust ingevolge de antiwitwaswetgeving een gelijksoortige bijzondere rechtsplicht om ongebruikelijke transacties door te geven. ${ }^{32}$ Indien de lijn van A-G Vegter zou worden gevolgd, dan zou dit impliceren dat het niet of niet tijdig melden van deze ongebruikelijke transacties kan worden aangemerkt als verhullende handeling. Daarmee zou de witwasgedraging van de bank zijn gegeven. Alles komt dan aan op de vraag of de subjectieve vereisten voor witwassen eveneens zijn vervuld.

Zoals gezegd concentreert de aangifte zich alleen op de in artikel 420bis lid 1 sub a $\mathrm{Sr}$ genoemde gedragingen. De gedragingen uit sub $b$ - verwerven en voorhanden hebben - worden opvallend genoeg niet naar voren gebracht. Dit terwijl deze gedragingen vermoedelijk veel eenvoudiger zijn aan te tonen. Een op verhulling van de criminele herkomst gerichte handeling is hiervoor in

27. HR 18 oktober 2013, NJ 2013/496. Vgl. HR 7 oktober 2014, NJ 2014/500 m.nt. Keijzer.

28. HR 26 oktober 2010, NJ 2010/655 m.nt. Keijzer.

29. HR 5 juli 2016, NJ 2016/334.

30. CAG 8 april 2014, ECLI:NL:PHR:2014:1144 onder 12.4.

31. HR 4 november 2014, ECLI:NL:HR:2014:3088.

32. Deze verplichting is in Nederland vastgelegd in artikel $16 \mathrm{Wwft}$. Het Amerikaanse equivalent daarvan zou volgens de aangifte zijn neergelegd in de Bank Secrecy Act. beginsel immers geen vereiste. Bovendien gaat het hier om vermogen dat middellijk uit misdrijf is verkregen door tussenkomst van de kartels. De door de Hoge Raad ontwikkelde kwalificatie-uitsluitingsgrond vindt daardoor sowieso geen toepassing. ${ }^{33}$

\subsection{Wetenschap}

Voorts vergt witwassen wetenschap van de criminele herkomst van de geldbedragen (art. 420bis $\mathrm{Sr}$ ), of in ieder geval dat de bank die herkomst redelijkerwijs had moeten vermoeden (art. 420quater Sr). Dergelijke wetenschap vergt een concreet aanknopingspunt. Het enkele bekend zijn met het feit dat iemand geen of weinig wit inkomen heeft, is daarvoor nog onvoldoende. ${ }^{34}$ De omvang van de onderzoeksplicht in het kader van schuldwitwassen zal daarbij sterk worden bepaald door de omstandigheden van het geval. ${ }^{35}$ Indien de voornoemde wetenschap kan worden aangetoond, kan het enkel opzettelijk ter beschikking stellen van de bij haar aangehouden bankrekeningen door de bank overigens al medeplichtigheid aan witwassen opleveren. ${ }^{36}$ Dat laatste is relevant nu de bank zelf niet degene is geweest die het geld heeft gestort, noch degene die deze storting van een bepaalde (schijn)titel heeft voorzien. Mocht de bovenstaande aan A-G Vegter ontleende argumentatie dus geen standhouden, of mocht toepassing van sub b op bezwaren stuiten, dan kan de bank niet als pleger doch hoogstens als deelnemer worden aangemerkt.

Complicerende factor bij de beoordeling van wetenschap is dat de bijkomende op verhulling gerichte gedragingen (het herhaaldelijk doorsluizen van het geld naar andere rekeningen) vooral in een later stadium lijken te zijn verricht, zonder dat de bank daar nog bij betrokken was. Haar gedragingen zien vooral op het ontvangen en bijboeken van het geld op diverse bankrekeningen, oftewel het kortstondig voorhanden hebben, en het niet-melden van die ontvangsten bij de aangewezen autoriteiten. Om die reden is het ook des te opvallender dat de aangifte aan sub b voorbijgaat. Dat gegeven is cruciaal nu de bank de wetenschap omtrent de criminele herkomst van dat geld moeten hebben op het moment dat zij de haar verweten witwashandelingen verricht. Behoudens het geval dat het geld zich nog steeds in de beschikkingsmacht van de bank bevindt, bijvoorbeeld doordat het op de rekening van een van haar rekeninghouders staat, zal wetenschap op een later

33. HR 25 maart 2014, NJ 2014/302 m.nt. Keijzer. De wijze waarop de aangifte is ingestoken roept overigens de vraag op of de aangifte de door de kartels begane grondfeiten langs die weg niet mede tot eigen misdrijven van de bank verheft. De aangifte beweert immers uitdrukkelijk dat de bank onderdeel uitmaakte van de criminele organisatie van de kartels en daarmee ook hun oogmerk deelde en een bijdrage leverde aan de verwezenlijking daarvan. Indien die betooglijn zou worden gevolgd, dan lijkt de consequentie daarvan te zijn dat de strafbare feiten die door die criminele organisatie worden begaan, in ieder geval voor een deel, ook als eigen strafbare feiten van de bank (als zijnde deelnemer aan die organisatie) hebben te gelden.

34. CAG 17 december 2013, ECLI:NL:PHR:2013:2423; CAG 13 mei 2014, ECLI:NL:PHR:2014:650.

35. Zie bijvoorbeeld HR 1 juli 2014, ECLI:NL:HR:2014:1588.

36. Vgl. HR 5 januari 2016, ECLI:NL:HR:2016:11. 
tijdstip niet kunnen bijdragen aan een veroordeling voor witwassen. ${ }^{37}$

De vraag is dus op welk moment de bank wist of moest weten dat de bedragen uit misdrijf afkomstig waren. Vanaf dat moment kan immers pas sprake zijn van witwassen. Cruciale vraag daarbij zal zijn wie binnen de bank over welke kennis beschikte en of die kennis kan worden toegerekend aan de bank. De in de aangifte genoemde argumentatie - het 'ongebruikelijke' karakter van de transacties, bestaande uit de locatie, frequentie, omvang en wijze van aanbrengen van de geldbedragen, en mogelijk gebrekkig toezicht - kunnen bouwstenen bieden voor de aanname van opzet, maar dan moet die kennis wel kunnen worden toegerekend aan alle in de aangifte genoemde onderdelen van bank. Of dat het geval is, is echter nog maar zeer de vraag. Daarmee komt tegelijkertijd de crux van de aangifte in beeld. Dat er in casu sprake is geweest van witwassen en een criminele organisatie staat niet zozeer ter discussie. De vraag is vooral of die gedragingen kunnen worden toegerekend aan en doorberekend binnen de bank naar de in Nederland gevestigde rechtspersonen en of de bank als geheel kan worden aangemerkt als lid van de criminele organisatie. Op dat punt makt de aangifte vrij eenvoudig grote sprongen. Dat iedere rechtspersoon in beginsel uitsluitend aansprakelijk is voor eigen gedragingen en dat het strafrecht geen concernaansprakelijkheid kent, ${ }^{38}$ lijkt daarbij enigszins over het hoofd te zijn gezien.

\subsection{Toerekening in concernverhoudingen: de gedraging}

Hoe zit het dan met die aansprakelijkheid in concernverhoudingen? Daarvoor moet allereerst worden gekeken naar het reguliere beoordelingskader voor de aansprakelijkheid van rechtspersonen. Volgens vaste jurisprudentie moet het daderschap van de rechtspersoon worden beoordeeld aan hand van het in het Drijfmestarrest geformuleerde stappenplan. Kernvraag die daarbij voorligt is of de verrichte gedragingen in redelijkheid aan de rechtspersoon kunnen worden toegerekend, hetgeen in beginsel het geval is indien die gedragingen in diens sfeer hebben plaatsgevonden. Omstandigheden die voor dergelijk plaatsvinden in de sfeer van de rechtspersoon indicatief kunnen zijn, zijn:

- de gedraging is verricht door iemand die werkzaam was ten behoeve van de rechtspersoon;

- de gedraging past in de normale bedrijfsvoering van de rechtspersoon;

- de gedraging is de rechtspersoon dienstig geweest; en

- de rechtspersoon kon beschikken over het plaatsvinden van de gedraging en heeft dat plaatsvinden ook aanvaard, waarbij onder aanvaarding mede moet worden begrepen het niet betrachten van de zorg die in redelijkheid van de rechtspersoon kon worden

37. Diepenmaat 2016, p. 87-88. Witwassen is immers een voortdurend delict zodat verbergen en verhullen ook het verborgen of verhuld houden omvat (HR 22 april 2014, NJ 2014/304; HR 9 december 2008 NJ 2009/147 m.nt. Borgers).

38. Kristen 2010, p. 157-158; Enneking e.a. 2016, p. 249. gevergd met het oog op de voorkoming van de desbetreffende gedraging. ${ }^{39}$

Voor wat betreft de vaststelling van opzet en schuld van rechtspersonen kan uit het overzichtsarrest inzake feitelijk leidinggeven worden afgeleid dat beide zowel kunnen worden toegerekend van een of meerdere natuurlijke personen aan de rechtspersoon, als dat het vervullen van deze subjectieve bestanddelen kan worden afgeleid uit het beleid of de dagelijkse gang van zaken binnen de rechtspersoon zelf. ${ }^{40}$ In de literatuur is inmiddels breed aanvaard dat dit jurisprudentiële kader ook kan worden gehanteerd voor de vaststelling van aansprakelijkheid in concernverhoudingen. ${ }^{41}$

Deze vraag naar toerekening van gedragingen en intenties in concernverhoudingen krijgt in de aangifte echter nauwelijks aandacht. Zelfs al zou bij wijze van hypothese worden aangenomen dat de vestiging in Calexico zich schuldig heeft gemaakt aan witwassen, dan wil dat nog niet zeggen dat die gedragingen (en het benodigde opzet) kunnen worden toegerekend aan de overkoepelende Amerikaanse tak van de Rabobank, laat staan aan de moedermaatschappijen in Nederland. Er zal derhalve moeten worden beoordeeld of toerekening hier gerechtvaardigd is, of dat aansprakelijkheid wellicht langs een andere weg vorm kan krijgen. In dit kader is overigens opvallend dat de aangifte de mogelijkheid van feitelijk leidinggeven door de moedermaatschappij in Nederland niet als optie lijkt te onderkennen, terwijl deze mogelijkheid inmiddels ook door de Hoge Raad expliciet is aanvaard. $^{42}$

In casu gaat het om gedragingen die (geabstraheerd van hun verboden karakter) ${ }^{43}$ behoren tot de normale operationele bancaire dienstverlening en dus onder de bedrijfsvoering van de rechtspersoon kunnen worden geschaard, in ieder geval van de werkmaatschappijen van de bank. Deze gedragingen - het oogluikend toestaan van het storten (en daarmee verwerven en voorhanden hebben) en overmaken van bedragen en het niet inseinen van de aangewezen instanties (verhullen) - zijn (indien bewezen) bovendien verricht door personen die werkzaam zijn ten behoeve van de rechtspersoon en zij zijn de rechtspersoon dienstig geweest. Aldus is sowieso al aan drie van de vier in het Drijfmestarrest genoemde

39. HR 21 oktober 2003, NJ 2006/328 m.nt. Mevis.

40. HR 26 april 2016, NJ 2016/375 m.nt. Wolswijk r.o. 3.4 .2 (Overzichtsarrest feitelijk leidinggeven). In het Drijfmestarrest zelf koos de Hoge Raad er nog uitdrukkelijk voor om deze vraag te laten rusten (zie HR 21 oktober 2003, NJ 2006/328 m.nt. Mevis, r.o. 3.5).

41. Kristen 2010, p. 132-139 en 155-174; Enneking e.a. 2016, p. 234-238 en 248-252 (met verdere verwijzingen aldaar); Hornman 2016a, p. 259-269.

42. HR 26 april 2016, NJ 2016/375 m.nt. Wolswijk r.o. 3.5.1 (Overzichtsarrest feitelijk leidinggeven)

43. HR 29 maart 2005, ECLI:NL:HR:2005:AR7619 (Mazen in het net); CBb 22 maart 2011, JB 2011, 126. Zie over het abstraheren van gedragingen van hun verboden karakter nader R. van Elst, 'Daderschap van rechtspersonen na het Zijpe-arrest', in: C.P.M. Cleiren, Th. A. de Roos en M.A.H. van der Woude (red.), Jurisprudentie Strafrecht Select, Den Haag: Sdu Uitgevers 2006, p. 429 
omstandigheden voldaan. ${ }^{44}$ Niettemin betreft het hier gedragingen die evident indruisen tegen het officiële ondernemingsbeleid. Dat laatste is op zich niet direct doorslaggevend. Anders zou aansprakelijkheid eenvoudig kunnen worden voorkomen door paper compliance en een fraaie integriteitsverklaring. ${ }^{45}$ A-G Machielse stelt terecht dat goede intenties van de rechtspersoon deze niet kunnen vrijwaren van strafvervolging voor tekortkomingen die door zijn personeel worden begaan bij het verrichten van voor hem gebruikelijke gedragingen. ${ }^{46}$ In de zich hier aandienende casus lijkt zich echter, afgaande op berichten uit de media, de situatie voor te doen dat lokale medewerkers van het Calexico kantoor en/of de daarop toezicht houdende kantoren, het door de Amerikaanse tak van het concern uitgezette beleid niet alleen hebben genegeerd, maar ook doelbewust waarborgingsmechanismen hebben omzeild, waarbij anderen in de bank zijn misleid. Het Financieele Dagblad meldt: 'Uit de rechtbankdocumenten blijkt dat [M] er samen met andere, niet met name genoemde bankmedewerkers, gedurende langere periode voor zorgde dat verdachte praktijken niet verder werden onderzocht. Tegen de regels in zorgde hij ervoor dat er geen melding werd gemaakt van verdachte transacties en probeerde hij die in sommige gevallen juist te maskeren. Zo plaatste hij onder meer verdachte klanten op een interne lijst met zogenoemde "geverifieerde klanten." Lagere werknemers van de bank onderzochten de klanten op die lijst niet vanwege hun vermeend geverifieerde status. In 2009 stonden tien van zulke "goedgekeurde klanten" op die lijst; eind 2012 waren dat er duizend. [M] ging door met zijn activiteiten, zelfs nadat het ministerie van financiën sommige betrokken rekeninghouders al op de korrel had en naar aanleiding daarvan onderzoek deed. ${ }^{47}$ Mocht deze berichtgeving juist zijn, dan voert het wel erg ver om ongeclausuleerd vast te houden aan het uitgangspunt dat gedragingen die indruisen tegen het ondernemingsbeleid desondanks kunnen worden toegerekend indien zij tot de normale bedrijfsactiviteiten behoren of in het verlengde daarvan liggen. Aanvullende motivering van een bevestigend daderschapsoordeel is dan zeker op zijn plaats. De omvang en de duur van de maskerende activiteiten van de toezichthoudende afdeling waartoe $[\mathrm{M}]$ behoorde, zouden die toerekening mogelijk ook kunnen rechtvaardigen nu deze factoren duiden op een langdurig en ernstig tekort in het interne systeem van checks and balances. Dat laatste zou een

44. Het gegeven dat de ingestelde vervolging mogelijk een averechts effect heeft en reputatieschade oplevert, doet niet af aan het oorspronkelijk dienstige karakter van de gedraging (CAG 20 juni 2017, ECLI:NL:PHR: 2017:879 onder 4.5).

45. Dat neemt overigens niet weg dat de vraag in hoeverre een compliance programma naar Nederlands recht aansprakelijkheid uitsluitend of mitigerend kan werken, de nodige aandacht verdient. Literatuur en jurisprudentie op dit punt zijn schaars.

46. CAG 20 juni 2017, ECLI:NL:PHR:2017:879 onder 4.5. Zo ook Gritter: 'Waar gehakt wordt vallen spaanders' (E. Gritter, 'De strafbaarheid van de rechtspersoon', in: J.B.J. van der Leij (red.), Plegen en deelnemen, Deventer: Kluwer 2007, p. 52). Zie voor een recent voorbeeld HR 7 februari 2017, ECLI:NL:HR:2017:40.

47. W. Keuning, 'Ex-Rabo-employé erkent hinderen intern antiwitwasonderzoek in VS', Het Financieele Dagblad 15 januari 2018. substantieel eigen verwijt aan het adres van de bank opleveren.

Daarmee komt de laatste van de in het Drijfmestarrest genoemde omstandigheden in beeld: kon de bank over deze gedragingen beschikken en heeft zij die gedragingen aanvaard, in die zin dat zij niet die mate van zorg betracht die in de gegeven omstandigheden van haar mocht worden verwacht (IJzerdraadcriteria)? Gezien de op handen zijnde strafvervolging in de Verenigde Staten, beantwoordt de Amerikaanse justitie die vraag in ieder geval ontkennend. Ook naar Nederlands recht valt daar iets voor te zeggen. Anders dan wel eens wordt verondersteld, staat eigenmachtig en onbevoegd optreden door medewerkers in de praktijk veelal niet aan aansprakelijkheid in de weg, zeker niet indien die verweten gedragingen voorzienbaar waren en het uitgeoefende toezicht gebrekkig. ${ }^{48}$ Het wijzen naar een paar rotte appels binnen de onderneming zal de bank daarom waarschijnlijk niet vrijpleiten. Niettemin vormt dit gegeven mijns inziens wel reden om het daderschap van de bank voornamelijk te construeren (en uitdrukkelijk te motiveren) door gebruik te maken van daderschapscriteria die zien op het eigen verwijt dat de rechtspersoon in deze context kan worden gemakt - het criterium van de normale bedrijfsvoering zoals dat wordt gecorrigeerd door de zorgplicht uit de tegenwoordige invulling van de IJzerdraadcriteria ${ }^{49}$ - en minder gewicht toe te kennen aan klassieke, en daarmee wellicht wat ongenuanceerde, toerekeningsfactoren zoals het baatcriterium en het werkzaam zijn ten behoeve van. Dat zou ook aansluiten bij de beperkte jurisprudentie die er op dit terrein is. Als zou worden aangenomen dat hier daadwerkelijk sprake is van een paar 'rogue employees' (of erger: medewerkers die zelf deel uitmaken van de kartels), al dan niet handelend voor eigen gewin (of dat van de kartels), dan lijkt de heersende opvatting toch te zijn dat onder die omstandigheden het enkele gegeven dat de fysieke plegers deze strafbare feiten hebben kunnen plegen omdat zij daartoe door hun aanstelling bij de bank in de gelegenheid zijn gesteld of bij het delict gebruik hebben gemaakt van (hulp)middelen die door de bank ter beschikking zijn gesteld, onvoldoende is om daderschap van de rechtspersoon aan te nemen. ${ }^{50}$ Dat zou anders uitvallen indien er sprake is van een bijkomende

48. HR 24 mei 1977, NJ 1978/330 (Nicotinezuur); HR 27 januari 1948, NJ 1948/197 m.nt. Pompe (V\&D); Hornman 2016a, p. 47-48. De voornoemde regel wordt door J. de Hullu, Materieel strafrecht. Over algemene leerstukken van strafrechtelijke aansprakelijkheid naar Nederlands recht, Deventer: Wolters Kluwer 2015, p. 162 overigens naar voren gebracht in het kader van het functioneel daderschap van natuurlijke personen. In de praktijk wordt deze regel niettemin breder opgevat en eveneens toegepast op rechtspersonen, zie bijvoorbeeld de overwegingen van de officier van justitie in Hof Amsterdam 15 mei 2014, ECLI:NL:GHAMS:2014:1769 en 1770 (art. 12 Sv-procedure 't Hofnarretie).

49. Zie Hornman 2016a, p. 49. Daarmee bedoel ik dat het vallen onder de normale bedrijfsvoering in beginsel toereikend is voor de vaststelling van daderschap, tenzij blijkt dat de rechtspersoon afdoende heeft ondernomen om de specifiek aan die bedrijfsvoering verbonden risico's te voorkomen dan wel tot een acceptabele omvang terug te brengen.

50. Hof Amsterdam 15 mei 2014, ECLI:NL:GHAMS:2014:1769 en 1770 (art. 12 Sv-procedure 't Hofnarretje); CBb 12 mei 2015, ECLI:NL:CBB: 
eigen zorgplichtschending door de rechtspersoon, bijvoorbeeld bestaande uit het niet nemen van passende maatregelen nadat deze met de begane strafbare feiten bekend is geraakt. Gebrek aan en de beweerde afbouw van toezichtmechanismen zouden daarvoor bouwstenen kunnen bieden, al moet daarbij worden aangetekend dat de reductie van het toezichthoudend personeel in absolute aantallen meevalt: van negen naar zes personen. Daarnaast zegt deze enkele ontwikkeling vrij weinig wanneer zij niet mede wordt bezien in het licht van de algehele ontwikkeling van het personeelsbestand van de bank, de algehele investeringen in toezichtmechanismen (waaronder automatisering en digitalisering) en de toenmalige financiële crisis. De hantering van dergelijke meer op de eigen verantwoordelijkheid van de rechtspersoon toegesneden daderschapscriteria zou tegelijkertijd meer en beter passende aanknopingspunten bieden voor de vaststelling van opzet. Behoudens voor de vestiging in Calexico waar een klassieke toerekeningsconstructie voor de hand ligt, ${ }^{51}$ zou voor de aanname van opzet bij de overige rechtspersonen toch een aanknopingspunt moeten worden gevonden in het door deze rechtspersonen gevoerde beleid of de zich daarbinnen voltrekkende gang van zaken. ${ }^{52}$

Niettemin kent de hiervoor geschetste ruimte voor bredere toerekening van de gedragingen ook grenzen. Van enige betrokkenheid van de in Nederland gevestigde onderdelen van de bank (de focus van de aangifte) blijkt nergens. Dat de Amerikaanse justitie tot vervolging overgaat, vormt dus nog geen argument om, zoals de aangifte voorstaat, ook in Nederland tot strafvervolging over te gaan. Er is niets dat wijst op enige betrokkenheid bij of intensieve bemoeienis met de feitelijke gang van zaken aldaar door de Nederlandse concernonderdelen. Evenmin hebben die onderdelen een dubbelrol op zich genomen door naast de rol van aandeelhouder tevens als feitelijk bestuurder van de in de VS gevestigde rechtspersonen op te treden. Dat laatste zou een argument zijn om aan de afzonderlijke rechtspersoonlijkheid van de diverse concernonderdelen voorbij te gaan, maar van dergelijke omstandigheden blijkt niet. ${ }^{53}$ Aansprakelijkheid lijkt zich in eerste instantie dus tot de in de VS gevestigde rechtspersonen van de bank te beperken.

\subsection{Toerekening in concernverhoudingen: opzet}

Het daderschap en het opzet van de vestiging in Calexico staan eigenlijk niet ter discussie. Aldaar zijn immers structureel witwasgedragingen verricht die tot de normale bedrijfsvoering van de bank konden worden gerekend en tot de feitelijke gang van zaken binnen de bank behoorde. Waarschijnlijk is de vestiging ook om die reden gesloten. ${ }^{54}$ De vraag blijft evenwel of dat opzet

2015:150 (over het ter beschikking stellen middelen aan een zusteronderneming).

51. Vgl. HR 15 oktober 1996, NJ 1997/109 (Gezondheidscertificaat).

52. Vgl. HR 26 april 2016, NJ 2016/375 m.nt. Wolswijk (Overzichtsarrest feitelijk leidinggeven)

53. Vgl. Enneking e.a 2016, p. 249-250; Kristen 2010, p. 156-172.

54. I. Bökkerink, 'Rabobank: breder onderzoek naar witwassen via kantoor VS', Het Financieele Dagblad 22 maart 2017. ook kan worden toegerekend aan andere rechtspersonen binnen het concern. In de kern ligt daarbij dezelfde vraag voor als bij daderschap, zij het dat de toerekening van opzet doorgaans meer voeten in de aarde heeft dan het toerekenen van gedragingen. Veelal ligt hierin immers het verschil tussen het begaan van een overtreding en het begaan van een misdrijf besloten. In de voorliggende casus zou kunnen worden betoogd dat gebrekkig toezicht (in het licht van de nieuwe invulling van de IJzerdraadcriteria ${ }^{55}$ ) een argument zou kunnen vormen voor het toerekenen van de gedragingen, maar of daarmee ook afdoende is gerechtvaardigd om opzet toe te rekenen valt te betwijfelen. Het gegeven dat het ernaar uitziet dat de bank door haar eigen medewerkers is misleid en tegengewerkt roept toch de vraag op of het wel redelijk zou zijn om juist het opzet van die mensen die de bank doelbewust om de tuin hebben geleid toe te rekenen. Jurisprudentie op dit vlak is evenwel schaars. Uit het Gezondheidscertificaatarrest kan worden afgeleid dat toerekening van hiërarchisch laaggeplaatste medewerkers passend is indien het verweten strafbare feit verband houdt met de aan de desbetreffende medewerker toegekende taken, bevoegdheden en vrijheden. ${ }^{56}$ In de desbetreffende casus lijkt echter grote betekenis toe te komen aan het feit dat de betrokken medewerker uitdrukkelijk gemachtigd was en grotendeels de vrije hand had gekregen. Bovendien, al is niet geheel duidelijk in hoeverre daaraan gewicht toekomt, was de directeur van de onderneming op de hoogte van de door de medewerker verrichte verboden gedragingen. Voor dat laatste bevatten de aangifte en mediaberichten geen indicaties en van een dergelijke vrije hand lijkt hier evenmin sprake. Interne checks and balances zijn immers doelbewust omzeild. De fiscale kamer van de Hoge Raad lijkt overigens minder scheutig waar het gaat om toerekening van opzet door betekenis toe te kennen aan de mate van zorg die de rechtspersoon heeft betracht bij het opdragen van de werkzaamheden en het wel of niet aanwezig zijn van redelijke gronden om aan een behoorlijke taakvervulling door de desbetreffende medewerker te moeten twijfelen, in het bijzonder nu beide vragen vervolgens erg vanuit de positie van de ondernemingsleiding worden beoordeeld. ${ }^{57}$ In de desbetreffende casus lijkt het gegeven dat het management persoonlijk geen verwijt viel te maken doorslaggevend te zijn geweest voor het oordeel dat toerekening onder de gegeven omstandigheden niet paste. Daarmee heeft de fiscale kamer in mijn ogen een eis gesteld die in zijn algemeenheid niet bepalend zou moeten zijn, zeker niet bij grote ondernemingen.

55. Aanvaarden omvat tegenwoordig (in het kader van daderschap) ook het niet betrachten van de zorg die in redelijkheid kon worden gevergd met het oog op het voorkomen van de gedraging (HR 21 oktober 2003, NJ 2006/328 m.nt. Mevis).

56. HR 15 oktober 1996, NJ 1997/109 (Gezondheidscertificaat).

57. HR 29 mei 2015, ECLI:NL:HR:2015:1360. Zie hierover ook E. Gritter, 'De fiscaalrechtelijke beboetbaarheid van de rechtspersoon: een strafrechtelijk perspectief', Tijdschrift voor Sanctierecht \& Onderneming 2016, 6 (1) p. 29-33. 
Wat betekent het voorgaande voor de Rabocasus? Opzet bij de vestiging in Calexico lijkt evident. Het witwastoezicht op die vestiging werd echter verricht vanuit andere filialen waarvan niet duidelijk is of die tot dezelfde rechtspersoon behoren als de vestiging in Calexico. Mochten die filialen een eigen rechtspersoon vormen, dan zou toerekening van de witwasgedraging (minimaal in de zin van verborgen of verhuld houden) gezien het structurele karakter waarschijnlijk niet problematisch zijn. De vaststelling van opzet wordt evenwel complexer. Afgaande op de jurisprudentie kan dat oordeel naar beide kanten uitvallen, waarbij moet worden aangetekend dat men zelfs bij een bevestigend opzetoordeel alleen nog maar de aansprakelijkheid van de net boven de vestiging in Calexico geplaatste rechtspersonen heeft vastgesteld. Of ook de lokale moedermaatschappij Rabobank N.A. daarmee naar Nederlands recht aansprakelijk zou zijn, is nog maar de vraag. Dat zal geheel afhangen van de concernstructuur ter plaatse en de kennis die daarbinnen kan worden aangenomen. De aangifte richt zich echter niet tot Rabobank N.A., maar tot diverse moedermaatschappijen in Nederland. Aanknopingspunten voor enig opzet, zelfs in voorwaardelijke vorm, aan deze kant van de Atlantische oceaan bevat de aangifte echter niet. Ook in de mediaberichten die tot dusver zijn verschenen is er niets dat daarop wijst. Voor zover er ruimte is om de in Calexico begane witwasgedragingen breder toe te rekenen dan alleen aan de lokale vestiging, lijken de grenzen van die toerekening zich niet verder uit te strekken dan het Noord-Amerikaanse continent. Schuldwitwassen (art. 420quater Sr) zou iets meer ruimte voor toerekening creëren, maar ook die route lijkt problematisch nu de zorgplicht om corrigerend op te treden toch vooral bij Rabobank N.A. lijkt te liggen.

\subsection{Witwassen 'binnen' in plaats van 'door' concernstructuren}

Hoewel het bestaande jurisprudentiële kader voor vaststelling van daderschap, opzet en schuld van rechtspersonen ruimte biedt voor de toerekening van gedragingen en intenties van dochtermaatschappijen of haar medewerkers aan de moedermaatschappij, wordt in de aangifte vrij eenvoudig heen gestapt over het gegeven dat de bedrijfsvoering van de verschillende betrokken bedrijfsonderdelen op bepaalde vlakken, in ieder geval al in geografisch opzicht, uiteenloopt. Vanwege dat verschil kan eveneens worden betwijfeld in hoeverre kennis over mogelijke misstanden bij een kleine vestiging aan de Amerikaans-Mexicaanse grens doorsijpelt naar de hogere organisatieregionen. Daar komt bij dat de verantwoordelijkheid om deze kwestie naar behoren aan te pakken vooral bij de Amerikaanse tak van de bank lijkt te liggen en niet zozeer bij de in Europa gevestigde onderdelen. Toerekening van mogelijke misstanden in de VS aan het Nederlandse deel van de bank, laat staan

58. De aangifte is immers niet alleen gericht is tegen diverse rechtspersonen van het Raboconcern, maar ook tegen meerdere topleidinggevenden persoonlijk in hun vermeende hoedanigheid als feitelijk leidinggevers. De kans dat zij op de hoogte waren van die misstanden lijkt minimaal, aan zijn leidinggevenden, ${ }^{58}$ wordt daardoor erg moeilijk, zo niet onmogelijk.

Niettemin kan een vervolging wegens witwassen ook in dit opzicht uitkomst bieden, maar dan wel op een andere manier dan in de aangifte wordt uiteengezet. Het reguliere toerekeningsstramien uit de Drijfmestjurisprudentie zou namelijk vergen dat de gedragingen van de (medewerkers van de) vestiging in Calexico hetzij direct, hetzij getrapt, ${ }^{59}$ moeten kunnen worden toegerekend aan de in Nederland gevestigde genoemde rechtspersonen uit de aangifte. Een dergelijke toerekening van rechtspersoon op rechtspersoon kan zeer lastig worden, zeker in internationale verhoudingen. Uitgaande van de concernstructuur zoals deze in de aangifte wordt geschetst, zou een getrapte toerekening vergen dat de witwasgedragingen allereerst moeten kunnen worden toegerekend aan de lokale vestiging, vervolgens aan de Rabobank North America, daarna aan de Utrecht-America Holding Inc., aansluitend aan de Rabobank International Holding B.V. en uiteindelijk aan de algehele moedermaatschappij de Coöperatieve Rabobank U.A. In plaats van het opteren voor complexe toerekeningsconstructies waarbij gedragingen ten aanzien van het grondfeit binnen concerns worden doorberekend van de ene rechtspersoon aan de andere en de moedermaatschappij uiteindelijk aansprakelijk kan worden gesteld voor een door een achterkleindochter begaan strafbaar feit, zou de weg van het witwassen van de criminele verdiensten van de dochteronderneming kunnen worden bewandeld. In dat geval wordt de gedraging van de dochter niet aan de moeder toegerekend, maar begaat de moeder juist haar eigen delict, namelijk het witwassen van de opbrengsten uit het door de dochteronderneming begane strafbare feit. ${ }^{60}$ Eventuele rechtsmachtkwesties zouden daarmee direct zijn gepareerd, nu evident is dat de witwasgedraging plaatsvindt in Nederland. ${ }^{61}$

$\mathrm{Nu}$ het door de achterachterkleindochteronderneming ${ }^{62}$ begane strafbare feit in casu eveneens uit witwassen bestaat, wordt het verschil in benadering niet direct duidelijk. Wanneer dat delict echter wordt vervangen door een milieudelict wordt dit een stuk inzichtelijker. In de klassieke toerekeningsbenadering zou de door de dochter begane milieuovertreding worden toegerekend aan

terwijl kennis een cruciaal constitutief element is voor aansprakelijkheid (zie HR 26 april 2016, NJ 2016/375 m.nt. H.D. Wolswijk (Overzichtsarrest feitelijk leidinggeven); zie hierover nader M.J. Hornman, 'Feitelijk leidinggeven. Hoe een weinig vernieuwend arrest toch veel nieuws kan brengen; een kritische beschouwing', TBS\&H 2016b (3), p. 128-139). Recente berichtgeving over wetenschap aan de Nederlandse zijde van de bank is mijns inziens nog te speculatief om daar in dit stadium al vergaande consequenties aan te verbinden (zie W. Keuning, 'Spanningen bij anti-witwasteam VS bekend bij Rabo-directie', Het Financieele Dagblad 9 februari 2018; K. Haegens, 'Rabobankdirecteuren in VS wisten van misstanden in filialen bij Mexicaanse grens: een reconstructie', de Volkskrant 9 februari 2018 (www.volkskrant.nl)).

59. Zie hierover nader de bronnen genoemd in voetnoot 42 .

60. Kristen 2010, p. 150-151

61. Kristen 2010, p. 150; Enneking e.a 2016, p. 227

62. Mogelijk loopt de lijn nog verder door, maar dit is de minimale verhouding die volgt uit de toenmalige concernstructuur zoals deze in de aangifte wordt geschetst. 
de moeder, waardoor het delict van de dochter eveneens dat van de moederonderneming wordt. Kiest men echter voor de witwasroute, dan wordt gesteld dat enkel de dochter de pleger is van het milieudelict, maar dat de moeder de daarmee behaalde kostenbesparingen en de aldus gegenereerde extra winst, vervolgens heeft witgewassen door dit als zijnde legitieme winst op haar bankrekening bij te schrijven. Op dat laatste, het witwassen van de vermogensrechten die uit het milieudelict voortvloeien, wordt de moeder vervolgens aangesproken. Het voordeel van deze benadering is dat allerlei omslachtige toerekeningsconstructies daarmee kunnen worden omzeild. Hoe, waar en wie het grondfeit heeft begaan doet bij witwassen immers niet ter zake. Afdoende is dat er een grondfeit is waaruit dit vermogen afkomstig is. ${ }^{63}$ Daarnaast reflecteert deze benadering mogelijk ook beter de tussen moeder en dochter bestaande rechtsverhouding, namelijk die van werk- (dochter) en beheersmaatschappij (moeder). De milieuovertreding komt daarbij voor rekening van de werkmaatschappij, terwijl de moeder wordt aangesproken op haar financiële beheers- en toezichtstaken. Zeker wanneer besmet vermogen via meerdere rechtspersonen steeds verder het concern wordt ingezogen en directe betrokkenheid van de moedermaatschappij bij het strafbare feit van de dochteronderneming niet kan worden vastgesteld, maar wel kan worden aangetoond dat de moeder wist of moest weten dat het door de dochter gegenereerde vermogen deels uit misdrijf afkomstig was, kan het vestigen van aansprakelijkheid via deze route aantrekkelijk zijn. Deze door Kristen nader uitgewerkte benadering verschilt duidelijk van de benadering waarvoor de aangifte opteert. ${ }^{64}$ In de aangifte zijn het steeds dezelfde witwasgedragingen uit Calexico die van rechtspersoon op rechtspersoon worden doorberekend. In de benadering van Kristen begaan alle binnen het concern betrokken rechtspersoon juist hun eigen witwasgedraging door het in Calexico verkregen besmette vermogen te verwerven en voorhanden en versluierd te houden en vervolgens weer over te dragen aan de volgende rechtspersoon. Iedere rechtspersoon wordt aldus aangesproken op zijn eigen tekortschietende zorgplicht om witwassen te voorkomen.

Deze optie biedt vele voordelen boven het rücksichtslos toerekenen binnen concernverhoudingen of het vereenzelvigen van rechtspersonen. Overigens zou deze benadering de tot op heden nog relatief onbeantwoorde vraag in hoeverre eenmaal besmet vermogen ook besmet blijft, veel prominenter op de agenda zetten. ${ }^{65}$ Het duidelijk aanbrengen van een afbakening tussen onderling verbonden maar niettemin zelfstandige rechtspersonen uit hetzelfde concern is vanuit de witwasjurisprudentie bezien ook in een ander opzicht relevant. Wanneer dui- delijk wordt benadrukt dat de dochteronderneming een zelfstandig rechtssubject is en dat het door de dochter begane delict ook haar delict is en derhalve niet zonder meer als delict van de moedermaatschappij kan worden aangemerkt, dan heeft dit eveneens tot gevolg dat de door de Hoge Raad ontwikkelde kwalificatie-uitsluitingsgrond $^{66}$ die wellicht wel op zou gaan voor de dochteronderneming, geen toepassing vindt bij de moedermaatschappij. Voor haar is het grondfeit immers geen eigen misdrijf. Mede tegen die achtergrond ${ }^{67} \mathrm{kan}$ ook worden betwijfeld of de verdediging er wel altijd goed aan doet om zich bij strafbare feiten die in concernverband zijn begaan, tegen vereenzelviging te keren. Vereenzelviging heeft namelijk tot gevolg dat het verschil in rechtspersoonlijkheid wordt weggedacht, waardoor er uiteindelijk maar één rechtspersoon resteert als dader en er dus ook maar één straf kan worden opgelegd. Wordt het beginsel van rechtspersoonlijkheid daarentegen gerespecteerd, dan zijn er dus ook meerdere daders en kan aan ieder van die rechtspersonen afzonderlijk een sanctie worden opgelegd, zelfs voor uiteenlopende delicten. Het totaal van de vermogensstraffen zou daarbij aanzienlijk hoger kunnen uitvallen dan bij vereenzelviging het geval zou zijn.

\subsection{Riskante bedrijfsactiviteiten, witwassen en opzet}

Zoals de aangifte en bovenstaande analyse laten zien, is de reikwijdte van de strafbepalingen van witwassen zeer ruim. Daarmee legt de aangifte ook een fundamenteel probleem bloot: de kans op witwassen is een inherent aan bedrijfsactiviteiten van een bank verbonden risico, een zeer groot risico zelfs. Als gevolg daarvan, kan het vanaf een bepaalde omvang van de bancaire activiteiten eigenlijk niet anders dan dat de bank zich eveneens inlaat met niet-legale geldstromen. De aangifte lijkt voor wat betreft de aanname van voorwaardelijk opzet ook deels op die gedachte te steunen: het risico op witwassen is een binnen de bancaire sector welbekend risico en de drugscriminaliteit is in Mexico en de Amerikaans-Mexicaanse grensregio zo prominent aanwezig dat het niet anders kan dan dat dit risico zich ook verwezenlijkt. Ergo, het is onmogelijk om als bank in Mexico actief te zijn zonder dit aanmerkelijke witwasrisico te aanvaarden. Die stelling zal statistisch gezien ongetwijfeld juist zijn nu er tussen de miljoenen transacties die er dagelijks in die regio plaatsvinden, onvermijdelijk ook criminele geldstromen zitten. De vraag is echter of uit de keuze van een onderneming om actief te worden in een sector of een land waarin zaken als witwassen, belastingontduiking of corruptie welig tieren, een automatische aanvaarding van de kans dat de onderneming bij dergelijke feiten betrokken raakt mag worden afgeleid. Hoewel een (sterk) verhoogde zorgplicht hier zeker op zijn

66. Zie hierover nader M.J. Borgers, 'Rechtsvorming door de Hoge Raad en de reikwijdte van de strafbaarstelling van witwassen', DD 2013, p. 361-370; B.F. Keulen, 'Eenvoudig (schuld)witwassen', DD 2016, p. 117-129.

67. Zie Hornman 2016a, p. 267-269 voor enkele andere mogelijke neveneffecten. 
plaats is, zal een dergelijk automatisme voor velen te ver gaan. Tegelijkertijd laat deze argumentatie zich niet eenvoudig weerleggen. Preventieve maatregelen kunnen de kans op witwassen wel terugdringen, maar niet wegnemen. Puur vanwege het aantal transacties zou eigenlijk al kunnen worden geconcludeerd dat een bank onder deze omstandigheden niet langer oprecht kan menen dat witwasgedragingen zullen uitblijven. Dat zou, zoals de aangifte ook stelt, betekenen dat de bank het plaatsvinden daarvan ook bewust heeft aanvaard. Dat de bank wellicht nog vastklampt aan de ijdele hoop dat zij van dergelijke witwashandelingen zal blijven gevrijwaard, is onvoldoende om nog succesvol voor bewuste schuld te pleiten. Aanvaarding in de zin van voorwaardelijk opzet omvat immers veel meer dan willen in de betekenis die daarin in het normale spraakgebruik wordt toegekend. Ook de dader die diens gedraging doorzet terwijl hij weet dat hij in alle redelijkheid niet langer oprecht op het uitblijven van de voorzienbare gevolgen kan vertrouwen, wordt geacht opzettelijk te hebben gehandeld. Bewuste schuld ligt alleen dan voor wanneer de dader wellicht lichtvaardig, maar wel oprecht, rekende op, uitging van, vertrouwde op etc. een goede afloop. Hopen tegen beter weten in en zonder enige substantiële grond volstaat niet. ${ }^{68}$

De vraag is echter wel of het gegeven dat de bank in abstracto wist (of, in geval van art. 420quater Sr: had moeten weten) dat grote delen van het aangebrachte geld een criminele herkomst hadden, voldoende is voor een veroordeling. Witwassen lijkt een meer concrete wetenschapseis te stellen. Het is niet afdoende dat de bank wist dat grote delen van het binnen komende vermogen een criminele herkomst hadden. Nodig is dat de bank ook wist (of moest vermoeden) pelke delen een criminele herkomst hadden. Anders dan waar de aangifte op aanstuurt, ziet de wetenschapseis op ieder van de specifieke (concreet ten laste gelegde) voorwerpen afzonderlijk. Nu kan er op basis van bepaalde omstandigheden natuurlijk een witwasvermoeden rijzen ten aanzien van meerdere voorwerpen, maar dat is wat anders dan wetenschap aan te nemen op grond van statistische gegevens en kansberekeningen. Dat laatste is wat de aangifte lijkt voor te staan. Dit gegeven - het objectgebonden zijn van de wetenschapseis - maakt toerekening nog lastiger. Wetenschap bij de overige rechtspersonen van het sterke vermoeden dat de bedrijfsvoering van het kantoor in Calexico waarschijnlijk niet op orde is, zal immers niet afdoende zijn. Vergaande concretisering zal overigens niet nodig - en bij giraal geld ook onmogelijk - zijn, maar er zullen wel bijkomende omstandigheden moeten zijn waardoor deze transacties

68. Zie o.a. K. Engisch, Untersuchungen über Vorsatz und Fahrlässigkeit im Strafrecht, Berlijn: Otto Liebmann 1930, p. 176-179; A.J. Machielse, in: Noyon/Langemeijer/Remmelink Strafrecht, Sr, aant. 6.4 (online, bijgewerkt 1 mei 2016); C. Roxin, Strafrecht: Allgemeiner Teil. Band I. Grundlagen. Der Aufbau der Verbrechenslehre, München: C.H. Beck'sche Verlagsbuchhandlung 2006, p. 445-448; CAG bij HR 20 juni 2006, NJ 2006, 358. opvallen of, in de terminologie van de Wwft, ongebruikelijk zijn.

\subsection{Feitelijk leidinggeven als alternatief?}

Een interessante alternatieve aansprakelijkheidsmodaliteit die in de aangifte niet als zodanig als optie naar voren wordt gebracht, is de mogelijkheid om de Europese moedermaatschappijen van de bank aan te merken als feitelijk leidinggevers van de door de dochterondernemingen in de VS begane strafbare feiten. De aangifte lijkt deze mogelijkheid over het hoofd te zien en kiest er duidelijk voor om de aansprakelijkheid van de moedermaatschappijen te construeren middels toerekening door de gedragingen van de ene rechtspersoon op basis van de Drijfmestcriteria door te berekenen aan de andere rechtspersoon om uiteindelijk te eindigen bij de Coöperatieve Rabobank U.A., de algehele moedermaatschappij van het concern. Het eindresultaat van deze exercitie is dat de moedermaatschappij hierdoor zelf als (mede)pleger van het feitelijk door de dochter begane delict kan worden aangemerkt. Dat is een dogmatisch verdedigbare, maar in potentie zeer omslachtige constructie, zeker in complexe multinationale concernverhoudingen als de onderhavige. Dit terwijl artikel $51 \mathrm{Sr}$ zelf voorziet in een ogenschijnlijk eenvoudiger alternatief: de moedermaatschappij vervolgen als feitelijk leidinggever. Deze optie heeft als voordeel dat allerlei tussenschakels wegvallen. Op feitelijk leidinggeven worden immers geen andere deelnemingsvormen toegepast waardoor feitelijk leidinggeven aan feitelijk leidinggeven of het medeplegen van feitelijk leidinggeven gewoon als (sec) feitelijk leidinggeven worden gekwalificeerd. ${ }^{69} \mathrm{De}$ complexiteit van de vraag naar aansprakelijkheid in concernverhoudingen wordt daardoor in ieder geval enigszins gereduceerd. Daarnaast, en dat is wellicht van groter belang, geldt voor feitelijk leidinggeven een flexibeler opzetvereiste. De (mede)pleger moet om aansprakelijk te zijn zelf het benodigde delictsopzet hebben. Voor de feitelijk leidinggever is dat niet het geval. Daarvoor geldt een globaler of meer generiek opzetvereiste dat enigszins van het concrete ten laste gelegde delict is losgezongen. ${ }^{70}$ In situaties waarin het lastig kan zijn om opzet te bewijzen, biedt die iets soepelere norm mogelijk net genoeg ruimte om iemand toch aansprakelijk te stellen. Des te opvallender dus dat de aangifte deze mogelijkheid niet aanstipt.

\section{De bank als lid van een criminele organisatie}

Naast witwassen wordt de bank in de aangifte ook verweten dat zij deel heeft uitgemaakt van een criminele organisatie, meer in het bijzonder dat zij heeft deelgenomen aan de criminele organisatie die door de drugskar-

69. Sikkema 2010, p. 66; De Hullu 2015, 504; Hornman 2016a, p. 266.

70. Hornman 2016a, p. 72-75 en 266-267 (met verdere verwijzingen aldaar). 
tels wordt gevormd. De bank wordt dus niet verweten dat zij een op zichzelf staande criminele organisatie vormde, maar dat zij onderdeel uitmaakte van een bredere criminele organisatie van de drugskartels, dan wel om de kartels heen, die het oogmerk had om de door de kartels beoogde misdrijven te plegen, te ondersteunen of anderszins te bevorderen. ${ }^{71}$ Dat is een aanzienlijk verdergaande toepassing van artikel $140 \mathrm{Sr}$ dan tot dusver in de literatuur werd bepleit. Daarin wordt deze strafbepaling vooral naar voren gebracht als middel om strafrechtelijk te kunnen optreden in concernverhoudingen en de moedermaatschappij aan te spreken op haar betrokkenheid bij door haar dochterbedrijf begane misdrijven. ${ }^{72}$

\subsection{De argumentatie uit de aangifte}

Waarop berust de claim uit de aangifte? Kern van de aangifte is dat het verwijt aan het adres van de bank zich niet concentreert op louter afstandelijke faciliterende gedragingen die in zekere zin losstaan van de misdrijven die door de kartels zijn begaan, oftewel op het witwassen als zelfstandig delict. Het verwijt gaat verder en stelt dat de Rabobank door haar handelen direct en in aanzienlijke mate heeft bijgedragen aan het leed dat door de kartels is veroorzaakt als gevolg van het door de kartels uitgeoefende geweld (moord, marteling, gedwongen verdwijningen etc.) en grootschalige drugshandel. Door de wijze waarop de bank de kartels behulpzaam is geweest, heeft de bank, zo stelt de aangifte, de kartels in staat gesteld hun winsten te herinvesteren en zodoende hun criminele activiteiten voort te zetten en uit te bouwen. ${ }^{73}$ Daarmee zou de bank ook deelnemer zijn geworden aan de criminele organisatie van de kartels. Hieruit zou volgen dat de bank behoort tot het samenwerkingsverband en een aandeel heeft in de verwezenlijking van het oogmerk van de organisatie. Gesteld wordt dat de bank door haar faciliterende gedragingen die het witwassen mogelijk hebben gemaakt, een aandeel heeft gehad, dan wel ondersteuning heeft gegeven aan gedragingen die rechtstreeks strekken tot of verband houden met het verwezenlijken van het doel van de organisatie. $\mathrm{Nu}$ de bank wist van de witwasgedragingen en onvoldoende heeft ondernomen om die te voorkomen dan wel te beëindigen, heeft de bank de aanmerkelijke kans dat die gedragingen zich zouden voordoen ook aanvaard, zo stelt althans de aangifte. Daarmee had de bank wetenschap van het oogmerk van de organisatie en heeft zij opzettelijk een bijdrage aan de verwezenlijking van dat oogmerk gegeven. Op grond daarvan zou de bank als deelnemer kunnen worden aangemerkt. Niet noodzake-

71. Aangifte, p. 18

72. Zie uitvoerig Kristen 2010, p. 151-155. Enneking e.a. 2016, p. 227-228. Vgl. A.N. Kesteloo, Deelneming aan een criminele organisatie. Een onderzoek naar de strafbaarstellingen in artikel 140 Sr (diss. OU), Nijmegen: Wolf Legal Publishers 2011, p. 64-65; Y. Buruma, ‘De racistische criminele organisatie', AA 47 (1998) 2, p. 116; A.H.J. Swart, 'Verboden organisaties en verboden rechtspersonen', in: Ch.J. Enschedé e.a. (red.), Naar eer en geweten (Remmelink-bundel), Arnhem: Gouda Quint 1987, p. 621.

73. Aangifte, p. 14 lijk is immers dat de bank ook direct deelneemt aan de misdrijven waar het oogmerk van de kartels op ziet. ${ }^{74}$

\subsection{Behoren tot het samenwerkingsverband}

Dat de kartels zelf een criminele organisatie vormen met een misdadig oogmerk staat buiten kijf. De wijze waarop de aangifte de Rabobank Groep tot onderdeel maakt van die organisatie, verdient daarentegen meer aandacht. Bij die redenering kunnen namelijk de nodige vraagtekens worden geplaatst, terwijl daarbij ook de vraag rijst waarom de aangevers artikel $140 \mathrm{Sr}$ juist op deze manier toegepast willen zien. Het aanmerken van diverse onderdelen van het Raboconcern als zelfstandige criminele organisatie, losstaand van de drugskartels, en waarbij het oogmerk zich alleen uitstrekt tot het witwassen, biedt namelijk meer kansen op een succesvolle vervolging.

De vier voorwaarden voor strafbaarheid ex artikel 140 Sr zijn welbekend. Allereerst dient sprake te zijn van een organisatie, oftewel van een duurzaam en gestructureerd samenwerkingsverband. ${ }^{75}$ Voorts moet deze organisatie het plegen van misdrijven tot oogmerk hebben, hetzij als direct doel hetzij als middel om een verder gelegen (mogelijk legitiem) doel te verwezenlijken. ${ }^{76} \mathrm{De}$ betrokkene moet kunnen worden aangemerkt als deelnemer aan die organisatie. Dat wil zeggen dat deze behoort tot het voornoemde samenwerkingsverband en een aandeel heeft in, dan wel ondersteuning biedt aan, gedragingen die strekken tot of rechtstreeks verband houden met de verwezenlijking van het oogmerk om misdrijven te plegen. ${ }^{77}$ Ten slotte moeten deze deelnemingsgedragingen opzettelijk zijn verricht en dient de betrokkene in zijn algemeenheid kennis te dragen (in de zin van onvoorwaardelijk opzet) van het feit dat de organisatie het plegen van misdrijven tot oogmerk heeft. Het is niet nodig dat deze ook wetenschap heeft van één of verscheidene concrete misdrijven die door de organisatie worden beoogd. ${ }^{78}$

Aan het organisatievereiste voldoen de kartels zeker en de Rabobank an sich natuurlijk eveneens. De vraag is echter of zij ook een gezamenlijk samenwerkingsverband vormden. Die vraag is in het bijzonder interessant omdat een van de betrokkenen bestaat uit een multinationaal concern van meerdere zelfstandige rechtspersonen. $\mathrm{Nu}$ is in de jurisprudentie al lange tijd breed erkend dat ook rechtspersonen onderdeel kunnen uitmaken van een criminele organisatie, ${ }^{79}$ maar de vraag wanneer een moedermaatschappij in die context ook aansprakelijk is voor mogelijke wandaden van haar

74. Aangifte, p. 18-19.

75. HR 16 oktober 1990, NJ 1991/442 m.nt. Corstens, AA 40 (1991) 5 m.nt. Groenhuijsen (Mariënburcht)

76. HR 8 mei 1978, NJ 1978/314 m.nt. Van Veen (Rote Armee Fraktion); De Hullu 2015, p. 440; Kristen 2010, p. 153.

77. HR 18 november 1997, NJ 1998/225 m.nt. De Hullu (Onvoorwaardelijk opzet); HR 3 juli 2012, NJ 2012/656-658 m.nt. Keijzer (Hofstadgroep); HR 14 maart 2017, ECLI:NL:HR:2017:413.

78. HR 18 november 1997, NJ 1998/225 m.nt. De Hullu (Onvoorwaardelijk opzet); HR 8 oktober 2002, NJ 2003/64; HR 5 september 2006, NJ 2007/336 m.nt. Schalken; De Hullu 2015, p. 441.

79. De Hullu 2015, p. 440. 
dochter is nog niet opgehelderd. Van enig samenwerkingsverband tussen de kartels en de hogere regionen van de Amerikaanse tak van bank lijkt geen sprake. Er is in ieder geval niets in de aangifte dat daarop wijst. Dat verband is er mogelijk wel met de vestiging aan de Amerikaans-Mexicaanse grens. Het is bij wijze van gedachteexperiment in ieder geval interessant om de casus vanuit die optiek te bezien. Daarmee komt de toerekeningsvraag weer centraal te staan. Een ruimhartige toerekening van gedragingen en kennis binnen concernverhoudingen zou artikel $140 \mathrm{Sr}$ een vergaand en tot op heden ongekend bereik geven. In de tot dusver bekende jurisprudentie ging het steeds om actieve betrokkenheid van de rechtspersoon en diens bestuurders bij de criminele organisatie. ${ }^{80}$ In het hier voorliggende geval is mogelijk sprake van actieve betrokkenheid van de vestiging in Calexico en haar medewerkers, maar zijn daarmee ook automatisch Rabobank N.A. en de aangesproken Nederlandse concernonderdelen onderdeel van dit samenwerkingsverband? Als men die vraag tracht te beantwoorden vanuit de positie van de hoofdbesturen van deze rechtspersonen zal het antwoord op deze vraag ongetwijfeld negatief zijn. De vraag is echter of aan de positie van deze organen zoveel gewicht toekomt. ${ }^{81}$ De rechtspersoon is, zo wordt breed erkend, iets meer en iets anders dan een loutere verzameling van natuurlijke personen en kan ook niet worden vereenzelvigd met diens bestuur. ${ }^{82}$ De rechtspersoon kan zeer wel aansprakelijk zijn als de directie van niets wist. Voorts is niet vereist dat de deelnemer aan de criminele organisatie ook bekend was, laat staan heeft samengewerkt, met alle andere deelnemers aan de organisatie. ${ }^{83}$ De voorliggende casus zou daarmee, indien zou blijken dat men op de vestiging in Calexico daadwerkelijk moedwillig heeft meegewerkt aan witwassen door de kartels te faciliteren en vergaand behulpzaam te zijn om antiwitwasmaatregelen te omzeilen, erg interessant zijn om de grenzen van toerekening in concernverhoudingen nader af te bakenen, zeker nu de bank op toezichthoudend vlak in ieder geval volgens de Amerikaanse justitie de nodige verwijten kunnen worden gemaakt. De casus bevat sterke aanknopingspunten op basis waarvan het ook voor andere onderdelen van de Amerikaanse tak van de bank duidelijk moet zijn geweest dat er iets mis was op de vestiging

80. Daarnaast bestaat er van oudsher een neiging om de toepassing van artikel $140 \mathrm{Sr}$ te richten op de personen achter de rechtspersoon en de rechtspersoon zelf buiten beschouwing te laten omdat deze vooral als middel en niet zozeer als dader wordt gezien (zie bijvoorbeeld Rb. Rotterdam, 13 oktober 1995, Milieu en Recht 1996/24 m.nt. De Lange (TCR) en Hof Amsterdam 27 februari 2015, ECLI:NL:GHAMS:2015:654 en 655 (Klimop)).

81. Vgl. De Hullu 2015, p. 173-174.

82. A.L.J. van Strien, De rechtspersoon in het strafproces. Een onderzoek naar de procesrechtelijke aspecten van de strafbaarheid van rechtspersonen (diss. Leiden), Den Haag: Sdu Uitgeverij 1996, p. 77; E. Sikkema, 'De strafrechtelijke aansprakelijkheid van leidinggevenden in Nederland', in: E. Sikkema en P. Waeterinckx (red.), De strafrechtelijke verantwoordelijkheid van leidinggevenden - in de economische context Preadvies voor de jaarvergadering van de Nederlands-Vlaamse Vereniging voor Strafrecht 2010, Nijmegen: Wolf Legal Publishers 2010, p. 12.

83. HR 22 januari 2008, NJ 2008/72; Kesteloo 2011, p. 36. in Calexico. ${ }^{84}$ Niet alleen sprongen de transacties vanwege hun contante karakter, hoge frequentie en omvang in het oog. Ook het herhaaldelijk afleveren van deze grote sommen geld in gepantserde wagens zou toch de aandacht moeten trekken? ${ }^{85}$ Het is de vraag welke consequenties hier in het kader van toerekening aan mogen worden verbonden. Artikel $140 \mathrm{Sr}$ vereist immers alleen dat er sprake is van een organisatie. Aspecten als omvang, continuïteit van de leden, het als eenheid naar buiten treden, de aanwezigheid van interne hiërarchie en het bestaan van onderlinge en aan sanctionering onderhevige regels, leveren weliswaar indicaties op voor het bestaan van een organisatie, maar het ontbreken hiervan impliceert nog niet dat er geen sprake is van een organisatie. ${ }^{86}$ Ook het feit dat de samenwerking gebrekkig is of knullig verloopt, hoeft daar niet aan in de weg te staan. ${ }^{87}$ Discussie lijkt er wel te bestaan over de minimale organisatiegraad die nodig is om van een organisatie te kunnen spreken. Swart en De Vries-Leemans, die aarzelingen hebben bij het in potentie ruime toepassingsbereik dat door de Hoge Raad aan artikel $140 \mathrm{Sr}$ wordt gegeven, pleiten voor de voorwaarde van een soort afzonderlijke eenheid met een eigen dynamiek, regels en doel. ${ }^{88}$ Dat werkt ook door in het deelnemingsvereiste. Er dient in hun optiek sprake te zijn van een duidelijke binding van belangen, waardoor de betrokkene zich ook verplicht voelt om zich aan de wensen van de organisatie te conformeren; ${ }^{89}$ een eis die door de Hoge Raad uitdrukkelijk is verworpen. ${ }^{90}$ Hoewel vluchtige samenwerking tot de mogelijkheden behoort, ${ }^{91}$ lijkt gehele vrijblijvendheid niettemin problematisch te zijn. De eis van hiërarchie en sanctionering wordt in de jurisprudentie evenwel niet gesteld. Hoogstens kan worden gesproken van de noodzaak van een zeker besef van collectiviteit en de aanwezigheid van een onderling sociaal verwachtingspatroon. Het is immers dat patroon tezamen met de dynamiek die van de organisatie uitgaat waaruit het verhoogde risico op het begaan van strafbare feiten - de ratio van artikel $140 \mathrm{Sr}$ - voortvloeit. ${ }^{92}$

Tegen de achtergrond van de eerdere uitvoerige uiteenzetting bij witwassen, kan de toelichting hier beperkter blijven. Voor zover er ruimte is om bepaalde rechtspersonen uit het concern aan te merken als deelnemers, zal dat naast de desbetreffende vestiging in Calexico, eerder

84. De stelling dat het haast niet anders kan dan dat leidinggevenden van Rabobank N.A. betrokken waren (aangifte, p. 24), mist echter voldoende onderbouwing

85. R. Betlem, 'Rabobank zet $€ 310 \mathrm{mln}$ opzij wegens dreigende Amerikaanse boete', Het Financieele Dagblad 3 januari 2018 (www.fd.nl); I. Bökkerink, 'Rabobank: breder onderzoek naar witwassen via kantoor VS', Het Financieele Dagblad 22 maart 2017.

86. HR 2 februari 2010, ECLI:NL:HR:2010:BK5193 en BK5175 r.o. 4.4; Kesteloo 2011, p. 37-38 en 65. lets terughoudender: M.J.H.J. de Vries-Leemans, Art. 140 Wetboek van Strafrecht. Een onderzoek naar de strafbaarstelling van deelneming aan misdaadorganisaties (diss. Tilburg), Arnhem: Gouda Quint 1995, p. 31-36; Swart 1987, p. 614-615.

87. Kesteloo 2011, p. 36 en 250.

88. Swart 1987, p. 614-615; De Vries-Leemans 1995, p. 273-276.

89. De Vries-Leemans 1995, p. 178-183.

90. HR 2 februari 2010, ECLI:NL:HR:2010:BK5193 en BK5175 r.o. 4.4.

91. De Vries-Leemans 1995, p. 178.

92. Vgl. Swart 1987, p. 614 
beperkt blijven tot enkele rechtspersonen op het NoordAmerikaanse continent die in nauwe relatie staan tot die vestiging. Daar rust immers de primair toezichthoudende taak en speelt - als die al ergens kan worden aangenomen - de bovengenoemde dynamiek en het sociale verwachtingspatroon. In dat opzicht lijkt de aangifte door te schieten door de in Calexico verrichte gedragingen, zonder noemenswaardige onderbouwing, ook aan de Nederlandse moedermaatschappijen toe te rekenen. Een meer zelfstandige hantering van artikel $140 \mathrm{Sr}$, waarbij de bank (of delen daarvan) zelf als criminele organisatie was aangemerkt - los van de kartels -, zou waarschijnlijk meer ruimte creëren voor een verdergaande toerekening.

\subsection{Een organisatie los van de kartels?}

Een meer zelfstandige benadering zou tot voordeel hebben dat zowel het oogmerk van de organisatie als de organisatie zelf verder worden afgebakend, in die zin dat dit zich uitsluitend uitstrekt tot witwassen en niet tot de geweldsdelicten en alleen onderdelen van de bank zelf omvat. Dat eerste is relevant voor het opzet van de bank. Haar zorgplichtschending (de meest solide basis voor haar daderschap; zie par. 3.4) ziet enkel op het niet betrachten van de mate van zorgvuldigheid die van de bank mocht worden gevergd met het oog op het voorkomen van witwasactiviteiten. Wanneer structureel tekort is geschoten in die zorg, zou dat een belangrijke bewijsindicatie kunnen vormen voor de aanwezigheid van voorwaardelijk opzet bij de Amerikaanse tak van de bank. ${ }^{93}$ Daarmee zou ook het opzet van de bank op het volledige oogmerk van de organisatie zijn gegeven. Het doel van de organisatie zou dan zijn het profiteren van het zakendoen met partners die hun vermogen waarschijnlijk niet legaal hebben verdiend en waarmee eigenlijk geen zaken mogen worden gedaan. Een dergelijk geheel overlappend oogmerk is weliswaar niet noodzakelijk - wetenschap van specifieke misdrijven is immers geen vereiste,$-{ }^{94}$ maar wanneer de deelnemingsgedragingen van vermeende deelnemer zich reeds in de periferie van zowel de doelstellingen als van de organisatie zelf afspelen, zoals het geval is bij de betrokkenheid bij de door de kartels begane mensenrechtenschendingen, kan daardoor wel de vraag rijzen in hoeverre de betrokkene daadwerkelijk tot het samenwerkingsverband behoort. In dat opzicht fungeren de subjectieve en objectieve componenten van artikel $140 \mathrm{Sr}$ enigszins als communicerende vaten. ${ }^{95}$ Een relatief bescheiden bijdrage aan de verwezenlijking van het oogmerk kan worden gecompenseerd door evident opzet. Tegelijkertijd zal bij een substantiële bijdrage sneller genoegen worden genomen met minder duidelijk opzet. Blijkt daarentegen dat de wetenschap van de betrokkene over de reikwijdte

93. Vgl. Wolswijk in diens noot onder HR 26 april 2016, NJ 2016/375 (Overzichtsarrest feitelijk leidinggeven).

94. Zie HR 8 oktober 2002, NJ 2003/64; HR 5 september 2006, NJ 2007/336 m.nt. Schalken; Kesteloo 2011, p. 55-57 en 252-253.

95. De Vries-Leemans 1995, p. 45-46, 188 en 281; J. ten Voorde, in: Tekst \& Commentaar Strafrecht, Deventer: Kluwer 2016, art. 140 Sr, aant. 10 onder b. (online, bijgewerkt 1 september 2017). van het oogmerk wezenlijk achterblijft bij de realiteit en zijn diens contributies aan de verwezenlijking van dat oogmerk ook nog eens beperkt, dan rijst toch serieus de vraag of de betrokkene wel echt onderdeel uitmaakt van de organisatie. ${ }^{96}$

Bij de geweldsdelicten van de kartels heeft de bank zelf geen direct belang. Dat de bank het oogmerk mist om die specifieke (gewelds)delicten te plegen, hoeft zoals gezegd niet doorslaggevend te zijn. Het is niet noodzakelijk dat alle aangesloten partijen het oogmerk in dezelfde mate onderschrijven. ${ }^{97}$ Voor de organisatie is zelfs voldoende dat deze het plegen van misdrijven accepteert als middel om een verder gelegen (legitiem) doel te realiseren. ${ }^{98}$ Van dat oogmerk moet de bank echter wel op de hoogte zijn geweest in de zin van onvoorwaardelijk opzet. ${ }^{99}$ De bank moet dus positieve kennis hebben gehad van de criminele doelstelling van de organisatie. Kennis van concrete misdrijven is geen vereiste. Voorts moeten de gedragingen van de bank strekken tot het verwezenlijken van dat oogmerk. Dat vergt een doelgerichte handeling, welke ook nog eens een daadwerkelijke feitelijke bijdrage moet leveren in die zin dat het gevaar op verwezenlijking van het oogmerk wordt vergroot. ${ }^{100}$ Niet nodig is dat de bank ook zelf deelneemt aan die misdrijven. Zoals de aangifte terecht stelt, volgt uit artikel 140 lid $4 \mathrm{Sr}$ nog eens expliciet dat de bijdrage ook kan bestaan uit het verlenen van financiële ondersteuning. ${ }^{101}$ Het niet afdoende optreden tegen witwaspraktijken is in het verleden reeds onder artikel $140 \mathrm{Sr}$ geschaard. Het benodigde opzet is daarbij bovendien geconstrueerd op een wijze die ook in de voorliggende zaak uitkomst zou kunnen bieden, namelijk het bewust laten ontstaan en laten voortbestaan van een bedrijfscultuur waarin de regels omtrent het melden van ongebruikelijke transacties structureel niet worden nageleefd. ${ }^{102}$

Tegelijkertijd blijft een veroordeling twijfelachtig nu maar een klein deel van de bank, eigenlijk alleen de lokale vestiging en de afdelingen die daar direct toezicht op moesten houden, echt een verwijt valt te maken. $\mathrm{Zij}$ waren betrokken of hebben onvoldoende ingegrepen. De overige onderdelen van de bank zijn buitenstaanders. In dat laatste toont zich evenwel het bijzondere karakter van de rechtspersoon als rechtssubject. De rechtspersoon kan dader zijn, ook als zijn individuele leden of onderdelen geen of nauwelijks blaam treft. In veel gevallen is de rechtspersoon zelfs dader, middel en slachtoffer tegelijkertijd. Dat mogelijk onschuldige interne derden worden getroffen wanneer de rechtspersoon zou worden gestraft, is geen reden om van bestraffing af te zien. Een concreet verwijt is echter wel nood-

96. Vgl. De Vries-Leemans 1995, p. 188.

97. Kesteloo 2011, p. 55-57

98. HR 8 mei 1978, NJ 1978/314 m.nt. Van Veen (Rote Armee Fraktion). Al kunnen er wel problemen rijzen wanneer het plegen van misdrijven van louter ondergeschikte betekenis is (Swart 1987, p. 612-613).

99. Zie par. 4.2.

100. Aldus Keijzer in diens noot onder HR 3 juli 2012, NJ 2012/658 (Hofstadgroep).

101. Ook in dat geval dient de betrokkene evenwel te behoren tot het samenwerkingsverband (HR 14 maart 2017, ECLI:NL:HR:2017:413).

102. Zie HR 10 februari 2015, ECLI:NL:HR:2015:264. 
zakelijk, en dat verwijt lijkt zich in casu tot de rechtspersonen op het Noord-Amerikaanse continent te beperken. De aangifte bevat geen aanknopingspunten dat er ook vanuit Europa moest worden ingegrepen. In die zin is de aangifte ook atypisch. Het had meer in lijn met de jurisprudentie gelegen om de vestiging in Calexico en/of enkele van haar medewerkers aan te merken als (onderdeel van de) criminele organisatie. ${ }^{103} \mathrm{Zij}$ hadden dan een organisatie binnen een organisatie gevormd. De gehele bank behoort evident niet tot de kern van het criminele netwerk en mist een wezenlijk deel van het oogmerk van de overige organisatieleden, en draagt, zelfs als moet worden aangenomen dat zij positieve kennis heeft van dat oogmerk, maar in zeer beperkte mate bij aan de verwezenlijking van dat oogmerk. Mocht men de Nederlandse tak van het concern al lidmaatschap van een criminele organisatie verwijten, dan zou het eerder voor de hand liggen om dit verwijt zo in te kleden dat die tak een zelfstandige criminele organisatie vormde, geheel los van de kartels en de vestiging in Calexico. Haar oogmerk zou dan bestaan uit het witwassen van de criminele opbrengsten die voortvloeien uit de Amerikaanse bedrijfsactiviteiten van het concern, waarbij het verwijt zich toespitst op het punt dat zij onvoldoende zou hebben ondernomen om te voorkomen dat de door haar bijgeboekte winsten uit die activiteiten verschoond bleven van crimineel vermogen. Daarmee wordt de betrokkenheid bij en verantwoordelijkheid van de bank voor de door de kartels begane mensenrechtenschendingen echter wel vergaand gereduceerd en dat is nu juist wat de aangifte tracht te voorkomen. Witwassen is zoals gezegd geen slachtofferloos misdrijf. Dat is de boodschap en dat willen de aangevers ook terugzien in het verwijt aan de bank. Daar komt bij dat Nederland ingevolge de positieve verplichtingen die voortvloeien uit het EVRM, waar mogelijk gehouden is om schenders van fundamentele mensenrechten op een passende wijze ter verantwoording te roepen. De ruimte van het Openbaar Ministerie om een eigen opportuniteitsafweging te maken over de mate waarin vervolging haalbaar, maar bovenal gewenst is, wordt daardoor aanzienlijk gereduceerd. ${ }^{104}$ De koppeling aan die mensenrechtenschendingen maakt het derhalve voor het Openbaar Ministerie moeilijker om de aangifte simpelweg terzijde te schuiven.

\section{Slotbeschouwing}

De aangifte tegen de Rabobank Groep is er erg op gebrand om de op een vestiging in Calexico verrichte witwasgedragingen zo ver mogelijk door te berekenen aan andere rechtspersonen en leidinggevenden binnen het Raboconcern. Daarin schiet de aangifte zonder meer door en wordt, zoals in het voorgaande is betoogd, eenvoudig over fundamentele toerekeningsvragen heenge- stapt. Vanwege het heftige geweld dat door de kartels wordt uitgeoefend en de vele onschuldige slachtoffers die daarbij vallen, is deze activistische insteek echter begrijpelijk. Alleen door de Nederlandse top van de bank publiekelijk aan te spreken, kan de stelling dat wiswassen geen slachtofferloos misdrijf is daadwerkelijk op de agenda worden gezet. Het niet-naleven van meldplichten door financiële instellingen bij vermoedens van witwassen heeft, ook binnen de sector, nog te veel de status van relatief onschuldig delict en van een bedrijfsrisico dat er nu eenmaal bij hoort en zich eens in de zoveel tijd verwezenlijkt, ongeacht de maatregelen die daartegen worden genomen. De daarin doorklinkende relativering van de ernst van het verwijt en de gecreëerde morele distantie tot de grove mensenrechtenschendingen die door witwassen mogelijk worden gemaakt, vormen eigenlijk de echte achterliggende problematiek van deze casus. Witwassen is geen slachtofferloos misdrijf en het is terecht dat de aangifte door deze illusie heen prikt en aandacht vraagt voor het leed van de slachtoffers van het drugsgeweld in Mexico en de verantwoordelijkheid die westerse ondernemingen daar deels voor dragen.

Zoals in het bovenstaande is gebleken, kunnen de strafbaarstellingen van witwassen en deelname aan een criminele organisatie vanwege hun ruime strekking en flexibiliteit uitkomst bieden in situaties waarin de reguliere deelnemingsvormen geen adequaat antwoord bieden om indirecte betrokkenheid van rechtspersonen bij ernstige mensenrechtenschendingen te redresseren. Niettemin is mijn verwachting dat een vervolging zoals in de aangifte wordt voorgestaan weinig kans van slagen heeft. Winst zal eerder moeten komen van een cultuuromslag en een hogere prioriteitstoekenning binnen de financiële sector zelf. De vraag is echter of dat gerealiseerd kan worden zonder een hogere positionering van witwaspreventie op de handhavingslijstjes van OM, AFM en DNB en blijvende aandacht van media en politiek. Gezien het feit dat er een jaar na indiening nog steeds geen inhoudelijke reactie is gegeven op de aangifte, blijft het noodzakelijk om hier aandacht voor te vragen. Hopelijk kan dit artikel, ondanks de kritische kanttekeningen, daaraan een verdere bijdrage leveren. 